\title{
Chemical and sensory quality of sheep liver pâté prepared with 'variety meat'
}

\section{Qualidade química e sensorial de patê de fígado ovino elaborado com subprodutos comestíveis}

\author{
Deborah Silva do Amaral ${ }^{1 *}$; Fábio Anderson Pereira da Silva ${ }^{2}$; \\ Taliana Kênia Alves Bezerra'; Ingrid Conceição Dantas Guerra²; \\ Paulo Sérgio Dalmás ${ }^{3}$; Katiuscia Menezes Lôbo Pimentel ${ }^{1}$; Marta Suely Madruga ${ }^{4}$
}

\begin{abstract}
Many edible meat by-products produced from sheep slaughter are often wasted but represent excellent sources of many nutrients. The preparation of pâte may be an alternative use for this raw material and may contribute to the development of a sheep sector by offering new products to the consumer market. The objective of this work was to produce and evaluate the quality of sheep pâté made with blood, liver and trimmed meat. The pâté formulation was composed of $12 \%$ meat, $25 \%$ liver, $13 \%$ blood, $20 \%$ water and $30 \%$ fat, as well as spices and seasoning. The product had high iron content $(9.0 \mathrm{mg} / 100 \mathrm{~g})$. The measured levels of essential amino acids exceeded the recommended values for adults. The sheep liver pâté showed a significant percentage of linoleic acid (16.68\%), which is essential to the human body. The pâté produced was in accordance with the requirements of the Brazilian legislation regarding chemical and microbiological parameters, able to be edible, and showed good sensory acceptance. This study suggests that the development of sheep liver pâte is a viable alternative to add value to edible sheep slaughter by-products by generating a product with high nutritional value.
\end{abstract}

Key words: Meat emulsions, sheep, pâté, quality, edible by-products

\section{Resumo}

Subprodutos comestíveis produzidos a partir do abate de ovinos são muitas vezes desperdiçado, mas representam excelentes fontes de muitos nutrientes. A preparação de patê pode ser uma alternativa para utilização desta matéria-prima e pode contribuir para o desenvolvimento do setor da ovinocultura, oferecendo novos produtos para o mercado consumidor. O objetivo deste trabalho foi produzir e avaliar a qualidade de patê ovino feito com fígado, sangue e retraços de carne. A formulação do patê foi composta de $12 \%$ de carne, $25 \%$ de fígado, $13 \%$ de sangue, $20 \%$ de água e $30 \%$ de gordura, bem como especiarias e condimentos. O produto tinha alto teor de ferro $(9,0 \mathrm{mg} / 100 \mathrm{~g})$. Os níveis medidos de aminoácidos essenciais excederam os valores recomendados para adultos. $\mathrm{O}$ patê de fígado ovino mostrou uma percentagem significativa de ácido linoleico (16,68\%), o que é essencial para o corpo humano. O patê produzido apresentou-se em acordo com as exigências da legislação brasileira sobre parâmetros químicos e microbiológicos, podendo ser consumido, e mostrou boa aceitação sensorial. Este estudo sugere que o desenvolvimento de patê de fígado de ovelha é uma alternativa viável para agregar valor aos subprodutos comestíveis do abate de ovinos, gerando um produto com alto valor nutritivo.

Palavras-chave: Emulsões cárneas, ovino, patê, qualidade, subprodutos comestíveis

1 Discente(s) da Universidade Federal da Paraíba, UFPB, João Pessoa, PB. E-mail: deborahamaral6@gmail.com; taliana.kenia@, hotmail.com; katiusciax@gmail.com

2 Profs.da Universidade Federal Rural de Pernambuco, UFRPE, Garanhuns, PE.E-mail: fabbiobass@hotmail.com; ingridcdantas@ hotmail.com

3 Prof. do Instituto Federal de Educação, Ciência e Tecnologia do Sertão Pernambucano, Petrolina, PE. E-mail: psdalmas@yahoo. com.br

4 Pesquisadora da UFPB, João Pessoa, PB. E-mail: msmadruga@uol.com.br

* Author for correspondence 


\section{Introduction}

The use of alternative sources of protein from the meat industry and its by-products can improve the nutritional status of the population at a low cost, especially in underdeveloped countries (FONTES et al., 2004, MATTOS et al., 2006). Worldwide, iron-deficiency anaemia is the most common nutritional disorder, affecting approximately 3.5 billion people. In Brazil, anaemia is an important endemic deficiency caused mainly by the lack of adequate food, low income and losses from wasted food (MOREIRA-ARAÚJO; ARAÚJO; ARÊAS, 2008). According to Dalmás et al. (2011), blood and liver are sources of high-quality protein and have excellent iron bioavailability, which can be useful in the prevention of anaemia when included in the human diet. In this context, an important task for the meat industry is maximal processing of edible by-products into food products, which favours the reduction of iron losses, increases the diversification of products to the consumer market, and adds an extra gain for the production chain.

Costa, Medeiros and Madruga (2003) reported that the use of goat slaughter by-products can increase income by $57.51 \%$ in relation to the carcass value. Dalmás et al. (2011) reported that the preparation of pâté is an alternative to the conventional use of goat blood and liver. In Europe, blood sausage and liver pâté are traditionally consumed (ESTÉVEZ; VENTANAS; CAVA, 2005, SANTOS et al., 2003).

Pâté is a cooked product with important gastronomic traditions and greatly appreciated sensory properties that is consumed in many countries (ECHARTE et al., 2004, VOSSEN et al., 2012). Studies have demonstrated the use of liver from different animal species such as pig (ESTEVÉZ et al., 2007, 2004; ECHARTE et al., 2004, D'ARRIGO et al., 2004), ostrich (FERNÁNDEZLÓPEZ et al., 2004), duck (ABU-SALEM; ABOUARAB, 2010), fish (AQUERRETA et al., 2002), chicken (ABU-SALEM; ABOU-ARAB, 2010, POLAK et al., 2011) and goat (DALMÁs et al., 2011) in the preparation of pâté, which highlights their nutritional and sensory properties. Given the above information and due to the scarcity of studies on the use of edible sheep slaughter by-products in the development of new products, particularly pâté, the aim of this work was to produce a pâté made with sheep blood, liver and meat trimmings and to determine its physicochemical, microbiological and sensory characteristics.

\section{Material and methods}

Preparation of sheep liver pâté

The basic formulation of pâté (Table 1) resulted from preliminary studies where varying concentrations of blood, liver and meat trimmings of sheep slaughtered between the ages of 18 and 24 months were considered to have better sensory acceptance. The drafting of the sheep liver pâté followed the methodology used by Dalmás et al. (2011) and was performed in triplicate. 
Table 1. Formulation of pâté prepared with sheep slaughter by-products.

\begin{tabular}{lcc}
\hline Raw Materials ${ }^{1}$ & Formulation in $\%$ & Formulation in $\mathrm{g} / 5 \mathrm{~kg}$ \\
\hline Blood & 13 & 650 \\
Liver & 25 & 1250 \\
Meat trimmings & 12 & 600 \\
Fat & 30 & 1500 \\
Water & 20 & 1000 \\
\hline Ingredients ${ }^{2}$ & & \\
\hline Stabilizer & 0.4 & 20 \\
Salt (Sodium chloride) & 1.5 & 75 \\
Curing salt (Nitrite) & 0.3 & 15 \\
Flavour enhancer & 0.1 & 05 \\
Powder garlic & 0.1 & 05 \\
Ham seasoning & 1.0 & 50 \\
Antioxidant & 0.4 & 20 \\
Soybean protein & 2.0 & 100 \\
Manioc starch & 1.5 & 75 \\
\hline
\end{tabular}

${ }^{1}$ Sum of raw materials accounted for $100 \%$ of the pâté formulation;

${ }^{2}$ Percentage added to the formulation of $100 \%$.

Source: Elaboration of the authors.

Physicochemical characterization and profile of minerals, amino acids and fatty acids

Moisture, ash, protein, nitrite and starch contents were determined using parameters described by AOAC (2000). The ether extract was characterised according to Folch, Less and Stanley (1957). The cholesterol content was measured according to methodology proposed by Bragagnolo and Rodriguez-Amaya (1997). A high resolution liquid chromatography instrument (VARIAN, Waters 2690, California, USA) with an INESTISIL C18 column (4.6 mm x $150 \mathrm{~mm}$ x $5 \mathrm{~mm}$ ) was employed for the determination of the cholesterol content in the samples. An isocratic elution of acetonitrile and isopropanol (60:40) with a constant flow rate of 1 $\mathrm{mL} / \mathrm{min}$ was used as the mobile phase. The detection of total cholesterol occurred in a UV-VIS detector (PDA 330) set at $210 \mathrm{~nm}$. The chromatographic separation was performed at $30{ }^{\circ} \mathrm{C}$ with a run time of $10 \mathrm{~min}$.

The water activity was measured according to parameters described by AOAC (2000) using a DECAGON apparatus (PAWKIT series P04266,
São Paulo, Brazil). The $\mathrm{pH}$ was determined using a digital $\mathrm{pH}$ meter (DIGIMED, model $\mathrm{pH} 300 \mathrm{M}$, São Paulo, Brazil) equipped with a glass electrode and the measurements were taken according to parameters described by AOAC (2000).

The colour parameters $\left(L^{*}, a^{*}, b^{*}\right)$ of the sheep liver pâté was determined according to the methodology described by Abularach, Rocha and Felício (1998) using a digital Minolta colorimeter (Model CR-300, Minolta, Osaka, Japan).

The determination of minerals $(\mathrm{P}, \mathrm{K}, \mathrm{Ca}, \mathrm{Na}$, $\mathrm{Mg}, \mathrm{Cu}, \mathrm{Cr}, \mathrm{Zn}$ and $\mathrm{Fe}$ ) was performed by plasma emission spectroscopy (BAIRS ICP-OES 2000, Massachusetts, USA) equipped with a $40 \mathrm{MHz}$ radio frequency source, a peristaltic pump and a spray chamber, which is in accordance with methodology described by Dalmás et al. (2011). The amino acid profile, using methodology by White, Hart and Fry (1986), was determined on a sample previously hydrolysed in $6 \mathrm{~N}$ bidistilled hydrochloric acid, followed by the pre-column derivatisation of the free amino acids with phenylisothiocyanate (PITC). The separation of the phenylthiocarbamyl 
amino acid derivatives (PTC-aa) was performed by liquid chromatography (VARIAN, Waters 2690, California, USA).

The characterisation of the fatty acids present in the lipid extract was obtained using the method of Folch, Less and Stanley (1957) and was performed as the methodology described by Hartman and Lago (1973). The identification and quantification of fatty acid esters was performed by gas chromatography (VARIAN, 430-GC, California, USA) coupled with an FID detector and a fused silica capillary column (CP WAX 52 CB, VARIAN) with film thickness dimensions of $60 \mathrm{~m} \times 0.25 \mathrm{~mm}$ and 0.25 $\mu \mathrm{m}$. Helium was used as the carrier gas $(1 \mathrm{ml} / \mathrm{min}$ flow rate). The initial oven temperature was $100{ }^{\circ} \mathrm{C}$ and was programmed to reach $240^{\circ} \mathrm{C}$ by increasing $2.5{ }^{\circ} \mathrm{C}$ per minute for 20 minutes. The injector and detector temperatures were maintained at $250{ }^{\circ} \mathrm{C}$ and $260^{\circ} \mathrm{C}$, respectively. The chromatograms were recorded with the Galaxie Chromatography Data System software. The fatty acids were identified by comparison of the retention time of corresponding methyl esters of samples using the Supelco ME19Kit standards (Fatty Acid Methyl Esters C6-C22). The fatty acid results were quantified using the standardisation of areas for the methyl esters and expressed as an area percentage.

\section{Sensory evaluation}

Before consumption by panelists, pâté samples were submitted to microbiological analysis, taking for the most probable number of thermotolerant coliforms, counts of coagulase-positive Staphylococcus (APHA, 2001), sulphite-reducing Clostridium (BRASIL, 2001) and Salmonella sp. (FDA, 2011).

The sensory analysis was performed by 60 untrained panelists, selected for being consumers of pâté or/and sheep-derived products or/and products made with blood and viscera. About $2 \mathrm{~g}$ of sheep liver pâté was served approximately $10{ }^{\circ} \mathrm{C}$ spread on bread slices, which average $2.5 \mathrm{~cm}^{2}$.

Panelists were asked to taste the samples for evaluation of attributes aroma, colour, flavour, texture and overall impression, using the nine-point hedonic scale as follows: 1 = disliked extremely, 5 $=$ neither liked $/$ or disliked, and $9=$ liked extremely. For the purchase intention test, a five-point structured scale was used, where 1 = Certainly would buy, 3 $=$ Maybe would buy / may would not buy and $5=$ Certainly would not buy. The sensory tests were performed according to methodology proposed by Meilgaard, Civille and Carr (1991), after approval by the Ethics Research Center of Health Sciences, Federal University of Paraíba (n. 0218/11).

\section{Results and Discussion}

Physicochemical quality, minerals, amino acids and fatty acids profile of sheep liver pâté

The physicochemical characterisation of pâté made with edible sheep slaughter by-products is shown in Table 2. The results are in accordance with the limits set by Brazilian legislation (BRASIL, 2000), which recommends a maximum content of 70 $\%$ moisture, $32 \%$ fat and $10 \%$ total carbohydrates with a minimum content of $8 \%$ protein.

The ash content $(3.72 \mathrm{~g} / 100 \mathrm{~g})$ of sheep liver pâté was similar to values reported by Dalmás et al. (2011) in pâté made with goat blood, liver and meat (3.13 g/100 g). However, sheep liver pâté showed mineral values higher than those reported by Estévez et al. (2007) and Echarte et al. (2004) in pig liver pâté that likely resulted from the use of sheep blood and liver, which are considered a good source of minerals (ANDERSON, 1988, FONTES et al., 2004). 
Table 2. Mean and standard deviation of physicochemical characterization of sheep liver pâté, goat pâté, liver pâté and lamb meat.

\begin{tabular}{lcccc}
\hline Parameters & Sheep liver Pâté & Goat Pâté & Liver Pâté $^{2}$ & Lamb Meat $^{3}$ \\
\hline Moisture $(\mathrm{g} / 100 \mathrm{~g})$ & $54.81 \pm 0.28$ & $54.93 \pm 0.51$ & 53.90 & 81.06 \\
Ash $(\mathrm{g} / 100 \mathrm{~g})$ & $3.72 \pm 0.08$ & $3.13 \pm 0.51$ & $\mathrm{NR}$ & $\mathrm{NR}$ \\
Protein $(\mathrm{g} / 10 \mathrm{~g})$ & $15.10 \pm 0.22$ & $14.74 \pm 0.07$ & 14.20 & 14.07 \\
Lipids $(\mathrm{g} / 100 \mathrm{~g})$ & $23.90 \pm 0.06$ & $22.67 \pm 0.07$ & 28.00 & 3.41 \\
Cholesterol $(\mathrm{mg} / 100 \mathrm{~g})$ & $115.08 \pm 0.20$ & $\mathrm{NR}$ & 255.00 & 36 \\
Starch $(\mathrm{g} / 100 \mathrm{~g})$ & $1.45 \pm 0.03$ & $4.53 \pm 0.00$ & 1.5 & $\mathrm{NR}$ \\
Nitrite $(\mathrm{mg} / \mathrm{kg})$ & $2.20 \pm 0.09$ & $\mathrm{NR}$ & $\mathrm{NR}$ & $\mathrm{NR}$ \\
$\mathrm{pH}$ & $7.25 \pm 0.04$ & $6.78 \pm 0.08$ & $\mathrm{NR}$ & $\mathrm{NR}$ \\
Aw & $0.97 \pm 0.00$ & $0.97 \pm 0.00$ & $\mathrm{NR}$ & $\mathrm{NR}$ \\
$L^{*}$ & $42.59 \pm 0.13$ & $49.31 \pm 0.29$ & $63.99 \pm 0.63$ & $\mathrm{NR}$ \\
$a^{*}$ & $18.37 \pm 0.25$ & $13.98 \pm 0.23$ & $10.23 \pm 0.38$ & $\mathrm{NR}$ \\
$b^{*}$ & $13.78 \pm 0.06$ & $13.91 \pm 1.46$ & $13.93 \pm 0.27$ & $\mathrm{NR}$ \\
\hline Minerals Profile & & & & \\
\hline Calcium $(\mathrm{mg} / 100 \mathrm{~g})$ & $9.40 \pm 0.10$ & $10.8 \pm 0.50$ & 70 & 7 \\
Copper $(\mathrm{mg} / 100 \mathrm{~g})$ & $1.15 \pm 0.04$ & $1.63 \pm 0.03$ & $\mathrm{NR}$ & $\mathrm{NR}$ \\
Iron (mg/100g) & $9.00 \pm 0.20$ & $6.48 \pm 0.09$ & 5.50 & 1.19 \\
Phosphorus (mg/100g) & $306 \pm 8.00$ & $249 \pm 6.00$ & 200 & 104 \\
Potassium (mg/100g) & $204 \pm 5.00$ & $204 \pm 2.00$ & 138 & 193 \\
Sodium (mg/100g) & $1337 \pm 10.0$ & $956 \pm 28.00$ & 697 & 43 \\
Magnesium (mg/100g) & $15.8 \pm 0.20$ & $19.7 \pm 1.60$ & 13 & 13 \\
Zinc (mg/100g) & $1.84 \pm 0.02$ & $2.27 \pm 0.04$ & 2.85 & 2.43 \\
\hline
\end{tabular}

${ }^{1}$ Adapted from Dalmás et al. (2011);

2,3 (USDA 2012a, 2012b);

NR: Not referenced.

Source: Elaboration of the authors.

In addition, sheep liver pâté has higher protein $(15.10 \mathrm{~g} / 100 \mathrm{~g})$ and lower lipid content $(23.90 \mathrm{~g} / 100$ g) when compared to values reported for pork liver pâté $[10.39 \mathrm{~g} / 100 \mathrm{~g}$ and $32.58 \mathrm{~g} / 100 \mathrm{~g}$ (ESTÉVEZ et al., 2004), $13.0 \mathrm{~g} / 100 \mathrm{~g}$ and $25.79 \mathrm{~g} / 100 \mathrm{~g}$ (ESTÉVEZ; VENTANAS; CAVA, 2005), 9.93 $\mathrm{g} / 100 \mathrm{~g}$ and $26.28 \mathrm{~g} / 100 \mathrm{~g}$ (ECHARTE et al., 2004), respectively] and fish pâté [12.97 g/100 g and 29.01 $\mathrm{g} / 100 \mathrm{~g}$ (AQUERRETA et al. 2002) and $9.85 \mathrm{~g} / 100 \mathrm{~g}$ and $24.86 \mathrm{~g} / 100 \mathrm{~g}$ (MINOZZO; WASZCZYNSKYJ; BOSCOLO 2010), respectively]. The addition of liver and blood to the formulation can also justify the high protein content. Anderson (1988) characterised viscera and found $20.99 \mathrm{~g} / 100 \mathrm{~g}$ of protein for lamb liver. The lamb is a young sheep (MADRUGA et al. 2007). Blood is considered a protein source of high commercial value with functional properties suitable for the preparation of emulsified products (SILVA; SILVESTRE, 2003).
The cholesterol content of sheep liver pâté (115 $\mathrm{mg} / 100 \mathrm{~g}$ ) was lower than that commonly found in literature for this type of product $(255 \mathrm{mg} / 100$ g), according to Echarte et al. (2004); however, it was higher than values reported by the same author for pig liver pâté ( 77.6 to $102 \mathrm{mg} / 100 \mathrm{~g}$ ). This fact can be attributed to the use of sheep liver in the formulation because according to Anderson (1988), the cholesterol content $(370 \mathrm{mg} / 100 \mathrm{~g})$ of sheep liver was higher than that of lamb meat $(66 \mathrm{mg} / 100$ g) as reported by Madruga (2009).

Given the increasing search for healthier food products, high cholesterol content is considered the most important disadvantage in meat products (ECHARTE et al., 2004). Thus, great efforts have been made to improve the quality of these products. To this end, the sheep liver pâté meets consumer demand as a product with lower cholesterol 
content when considering the remaining liver pâtés traditionally marketed.

The residual nitrite content $(2.20 \mathrm{mg} / \mathrm{kg})$ was lower than values established by Brazilian law (BRASIL, 1998), which recommends a maximum of $15 \mathrm{mg} / \mathrm{kg}$ of product. Sheep liver pâté has a residual nitrite content within the range reported by Pinho et al. (1998) for 15 brands of pig and poultry liver pâté, which ranged from 1.07 to 5.2 $\mathrm{mg} / \mathrm{kg}$. Doolaege et al. (2012) reported that the controlled use, in addition to the low residual nitrite concentration, reduced the risk of formation of nitrosamines, making nitrite safe for application in meat products.

Sheep liver pâté is a product with high Aw (0.97) and $\mathrm{pH}$ close to neutral (7.25), which characterises it as a product susceptible to microbiological changes. Similar behaviour was reported by Minozzo, Waszczynskyj and Boscolo (2010), indicating that these values make the product suitable for the development of pathogenic bacteria. Thus, packing the product in suitable packaging and storing under refrigerated conditions became necessary.

Colour is a quality attribute that directly influences the acceptability of meat products. Consequently, Stiebing (1990) recommends that the red colour intensity $\left(a^{*}\right)$ should have values above 20 to provide acceptable colour in blood meat products with added nitrite. The red intensity $\left(a^{*}\right)$ of sheep liver pâté is close to this limit with a value of 18.37. Lightness $\left(L^{*}\right)$ is another important parameter of meat products with added blood because the higher the blood concentration in the final product, the lower the brightness $\left(L^{*}\right)$, which thus reduces product attractiveness (Dalmás et al., 2011). This parameter can be justified by the high concentration of heme pigments present in blood, which are transformed into dark compounds by heat treatment (FONTES et al., 2004). All colour parameters $\left(L^{*}, a^{*}\right.$ and $\left.b^{*}\right)$ of sheep liver pâté were similar to values found by Dalmás et al. (2011) for goat pâté.
Sheep pâté had high potassium, phosphorus, magnesium and iron content, and significant contents of these minerals was reported by Abd Elaal and Suliman (2008) in lamb meat. The nutritional quality of sheep pâté, in regards to the iron content $(9 \mathrm{mg} / 100 \mathrm{~g})$, is related to the use of liver and blood in the formulation, which increased the iron content by approximately 7 times the iron content of meat. Anderson (1988) studied the mineral composition of lamb organs and found higher iron values for the liver $(7.47 \mathrm{mg} / 100 \mathrm{~g})$ compared to meat (1.3 $\mathrm{mg} / 100 \mathrm{~g})$. Dalmás et al. (2011) reported that increasing the blood level resulted in increased iron content (6.46 to $9.99 \mathrm{mg} / 100 \mathrm{~g}$ ) when developing goat pâté with added blood and liver. MoreiraAraujo, Araújo and Arêas (2008) and Dalmás et al. (2011) reported that iron from animal sources has excellent bioavailability, which makes it suitable for use in programs to control anaemia through the development of food products.

Likewise, zinc absorption is higher in animal protein-rich sources than in vegetal food (WILLIAMS, 2007). Unlike sodium, the zinc, calcium and copper contents are lower than values reported by Dalmás et al. (2011) for goat pâté. The high sodium concentration in sheep liver pâté is attributed to the addition of sodium chloride and sodium nitrite to the formulation.

The amino acid profile of sheep liver pâté (Table 3) exceeded the recommended values for adults (FAO, 2007) for liver pâté and lamb meat (USDA, 2012b, 2012c). In addition, based on the chemical score (PIRES et al., 2006), the sheep liver pâté showed no amino acid deficiencies; thus, it is a product regarded as a source of protein of high nutritional value. The content of essential amino acids in sheep liver pâté accounted for $53.80 \%$ of the total content, which indicates that this meat product is an excellent source of leucine, valine and histidine. For non-essential amino acids, it also showed high levels of aspartic and glutamic acids. 
Table 3. Amino acids profile (mg / g protein) of sheep liver pâté, FAO standard, amino acids, liver pâté and lamb meat scores.

\begin{tabular}{|c|c|c|c|c|c|}
\hline Amino acids & Sheep liver pâté & FAO standard $^{1}$ & Amino acids score ${ }^{2}$ & Liver pâté ${ }^{3}$ & Lamb meat $^{4}$ \\
\hline \multicolumn{6}{|l|}{ Essential } \\
\hline Phenylalanine & 56.95 & 38 & 1.50 & 40.99 & 40.70 \\
\hline Histidine & 74.17 & 15 & 4.94 & 20.99 & 31.64 \\
\hline Isoleucine & 52.20 & 30 & 1.74 & 39.01 & 48.25 \\
\hline Leucine & 112.58 & 59 & 1.91 & 73.94 & 77.78 \\
\hline Lysine & 47.68 & 45 & 1.06 & 59.01 & 88.29 \\
\hline Methionine & 48.1 & 22 & 2.19 & 20.00 & 25.67 \\
\hline Threonina & 64.2 & 23 & 2.79 & 40.00 & 42.81 \\
\hline Valine & 82.12 & 39 & 2.11 & 50.09 & 53.93 \\
\hline \multicolumn{6}{|l|}{ Non-essential } \\
\hline Alanine & 80.13 & NR & NR & 67.04 & 60.15 \\
\hline Arginine & 40.40 & NR & NR & 63.03 & 59.42 \\
\hline Aspartic acid & 139.07 & NR & NR & 81.90 & 87.98 \\
\hline Glutamic acid & 179.47 & NR & NR & 134.09 & 145.05 \\
\hline Glicine & 66.89 & NR & NR & 95.99 & 48.85 \\
\hline Proline & 19.21 & NR & NR & 70.07 & 41.91 \\
\hline Serine & 57.62 & NR & NR & 41.90 & 37.18 \\
\hline Tyrosine & 44.37 & NR & NR & 31.97 & 33.58 \\
\hline
\end{tabular}

${ }^{1}$ Estimated amino acid requirement (adults). Standard protein reference FAO / WHO / ONU (2007);

${ }^{2}$ Amino acid score (mg/g protein sample) / (mg/g protein standard FAO / WHO);

${ }^{3} \operatorname{USDA}(2012 \mathrm{~b})$;

${ }^{4} \operatorname{USDA}(2012 \mathrm{c})$;

NR: Not referenced.

Source: Elaboration of the authors.

The amino acid composition of sheep liver pâté can be credited to the use of blood, liver and sheep meat in the formulation. According to Gorbatov (1988), isoleucine and methionine deficiencies in the blood can be overcome by the combination of the meat with blood, thus maintaining adequate amounts of essential and nonessential amino acids. Anderson (1988) evaluated the amino acid composition in the viscera of lamb, which highlighted the high biological value due to the presence of all essential amino acids and revealed that the viscera has similar values to lamb meat.

Sheep liver pâté has a high percentage of monounsaturated fatty acids $(42.31 \%)$ with mainly oleic acid (Table 4), which is distinguished for its high concentration in sheep meat and pork fat (BRAGAGNOLO; RODRIGUEZ-AMAYA, 2002,
PELEGRINI et al. 2007). Linoleic acid (C18:2) stood out among the polyunsaturated fatty acids at $16.68 \%$. Estévez et al. (2004) reported a lower percentage of polyunsaturated fatty acids for pig liver pâté, especially in relation to the linoleic acid concentration ( $7.71 \%$ to $12.54 \%$ ). Anderson (1988) indicates that lamb organs have higher polyunsaturated fatty acid levels compared to those of fresh lamb meat, especially heart (15.85\%), kidney (20.83\%) and liver (23.57\%). Linoleic acid is considered essential to the human body due to its specific physiological functions like being a requisite compound in the tissue that makes up the central nervous system, and it also plays a role in the prevention of cardiovascular, autoimmune and inflammatory diseases (THAUTWEIN, 2001). 
Table 4. Fatty acid profile of sheep liver pâté, pig liver pate and lamb meat.

\begin{tabular}{lccc}
\hline Fatty acid $(\%)^{1}$ & Sheep liver Pâté & Pig liver Pâté & ${\text { Lamb } \text { meat }^{3}}^{{ }^{2}}$ \\
\hline SFA & 40.80 & 35.42 & 39.81 \\
C14:0 Myristic & $1.58 \pm 0.01$ & $1.12 \pm 0.01$ & 3.01 \\
C16:0 Palmitic & $25.27 \pm 0.13$ & $21.67 \pm 0.07$ & 22.92 \\
C18:0 Stearic & $12.03 \pm 0.06$ & $11.99 \pm 0.02$ & 13.88 \\
C20:0 Arachidonic & $1.00 \pm 0.01$ & $0.21 \pm 0.04$ & 1.16 \\
C22:0 Behenic & $0.39 \pm 0.05$ & $\mathrm{NR}$ & $\mathrm{NR}$ \\
C24:0 Tetracosanoic & $0.53 \pm 0.00$ & $\mathrm{NR}$ & $\mathrm{NR}$ \\
\hline MUFA & 42.31 & 52.55 & 25.23 \\
C14:1 cis-9-tetradecenoic & $0.03 \pm 0.00$ & $\mathrm{NR}$ & $\mathrm{NR}$ \\
C16:1 Palmitoleic & $0.42 \pm 0.00$ & $2.22 \pm 0.01$ & 3.47 \\
C18:1 Oleic & $41.86 \pm 0.18$ & $48.50 \pm 0.07$ & 21.76 \\
\hline PUFA & 16.88 & 10.05 & 3.94 \\
C18:2 Linoleic & $16.68 \pm 0.07$ & $10.01 \pm 0.08$ & 2.32 \\
C18:3 Linolenic & $0.20 \pm 0.04$ & $0.04 \pm 0.00$ & 1.62 \\
\hline
\end{tabular}

${ }^{1}$ SFA - Sum of saturated fatty acids, MUFA: Sum of monounsaturated fatty acids, PUFA: Sum of polyunsaturated fatty acids.

${ }^{2}$ Adapted from Estévez et al. (2004);

${ }^{3}$ Adapted from Madruga (2009);

NR: Not referenced.

Source: Elaboration of the authors.

\section{Sensory analysis}

The microbiological evaluation showed microorganism counts below limits established by legislation (BRASIL, 2001) for sulphite-reducing Clostridium ( $<100 \mathrm{CFU} / \mathrm{g})$, coagulase-positive Staphylococcus $(<100 \mathrm{CFU} / \mathrm{g})$ and thermotolerant coliforms ( $<3.0 \mathrm{MPN} / \mathrm{g})$ in addition to the absence of Salmonella sp.; therefore, the sheep liver pâté was deemed suitable for human consumption. Guerra et al. (2011) found similar results when preparing sausage with disposed goat meat. The excellent microbiological quality of the sheep liver pâté was a result of the combined effects of heat treatment to eliminate vegetative forms (SANTOS et al., 2005), the use of salt $(\mathrm{NaCl})$ to reduce water activity and inhibit the growth of microorganisms (HONIKEL, 2008), and the addition of nitrite to inhibit the growth of anaerobic bacteria, particularly Clostridium botulinum, as well as the growth of spores (SEBRANEK; BACUS, 2007). In addition to these factors, applications of Good Manufacturing Practices - GMP involving the quality of the raw material, hygienic processing conditions and cold storage were essential for the microbiological safety of the product.

The sheep liver pâté was positively evaluated in the acceptance test. This pâté received flavour scores corresponding to liked slightly (6.6) and aroma, colour and texture scores corresponding to liked moderately (7.1). The overall impression received a favourable score of 6.9. Regarding the purchase intention test, the average score received was 3.8 points, which corresponded to $58 \%$ (score 4 and 5) of the panellists that would buy the product, $22 \%$ (score 3 ) indicated doubt whether to buy or not and only $20 \%$ rejected the product (score 1 and 2). Guerra et al. (2011) reported similar results, indicating good acceptance, with scores ranging from 6 to 7.6 for the acceptance test and from 3.5 to 3.8 for the purchase intention test of goat mortadella prepared with different fat concentrations.

The frequency histogram of aroma, colour, flavour and texture attributes along with the overall appearance of the sheep liver pâté is shown in Figure 1. A trend of higher scores between 6 and 8 for all attributes was observed, with colour showing 
the highest acceptance index (84\%) and flavour with the lowest acceptance index (66\%). The highest flavour rejection was attributed to the strong flavour as reported by spontaneous comments from panellists. Aquarreta et al. (2002) indicated similar assessments for the same attribute, which was considered very strong in pâté made with tuna liver.

Figure 1. Histogram of frequency of scores assigned to attributes aroma, colour, flavour, texture and overall impression of sheep liver pâté evaluated in the acceptance test.

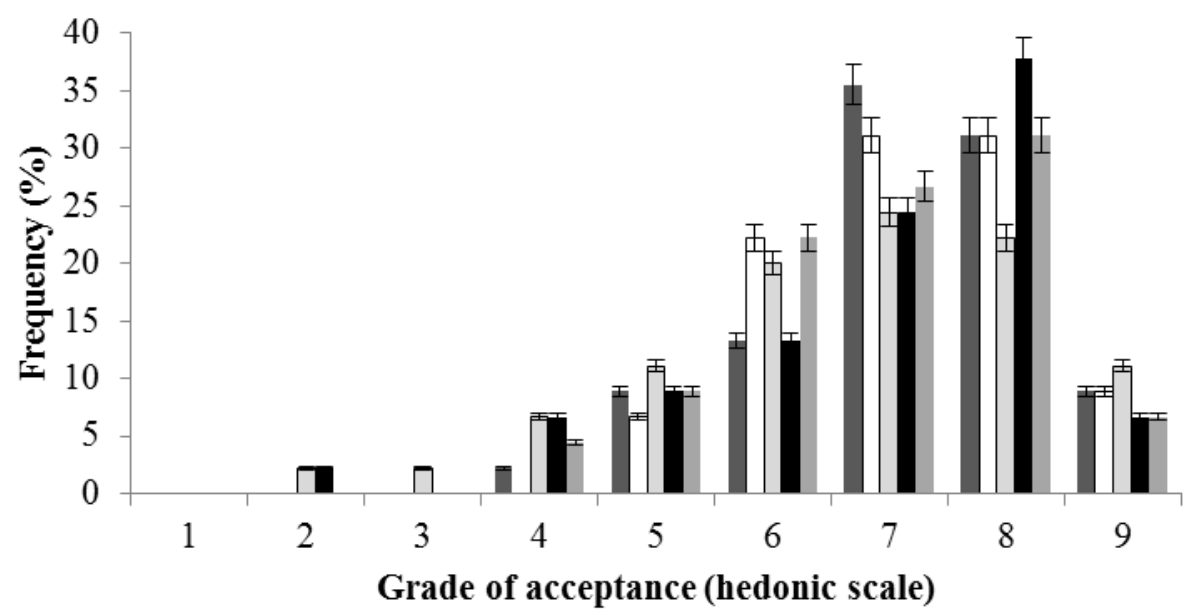

घ Aroma $\square$ colour $\square$ flavour $\square$ texture $\square$ overall impression

Source: Elaboration of the authors.

\section{Conclusion}

The characterisation of sheep liver pâté showed significant content of essential amino acids, protein, iron and linoleic acid in addition to good sensory acceptability. Therefore, the preparation of sheep liver pâté is a viable alternative to add value to sheep blood and liver that results in a product with high nutritional quality.

\section{Acknowledgments}

To the National Council for Scientific and Technological Development (CNPq) for financial support and the "Sertão Pernambucano" Federal Institute of Education, Science and Technology (IFSERTÃO-PE) for the meat processing laboratory where the products were developed.

\section{References}

ABD EL-AAL, H. A.; SULIMAN, A. I. A. Carcass traits and meat quality of lamb fed on ration containing different levels of leucaena hay (Leucaena Leucocephalal). Biotechnology in Animal Husbandry, Belgrade-Zemun, v. 24, n. 3, p. 77-92, 2008.

ABULARACH, M. L. S.; ROCHA, C. E.; FELÍCIO, P. E. Características de qualidade do contrafilé (m. 1. dorsi) de touros jovens da raça nelore. Ciência e Tecnologia de Alimentos, Campinas, v. 18, n. 2, p. 205-210, 1998.

ABU-SALEM, F. M.; ABOU ARAB, E. A. Chemical properties, microbiological quality and sensory evaluation of chicken and duck liver paste (foie gras). Grasas y Aceites, Washington, v. 61, n. 2, p. 126-135, 2010.

ANDERSON, B. A. E. Composition and nutritional value of edible meat by-products. In: PEARSON, A. M.; DUTSON, T. R. Edible meat by-products. London, 1988. cap. 1, p. 15-45. 
APHA. Compendium of methods for the microbiological examination of foods. $4^{\text {th }}$ ed. American public health association, Washington DC. 2001. 676 p.

AQUERRETA, Y.; ASTIASARÁN, I.; MOHINO, A.; BELLO, J. Composition of pâtés elaborated with mackerel flesh (Scomber scombrus) and tuna liver (Thunnus thynnus): comparison with commercial fish pâtés. Food Chemistry, Barking, v. 77, n. 2, p. 147-153, 2002.

ASSOCIATION OF OFFICIAL ANALYTICAL CHEMISTS - AOAC. Official methods of analysis. Washington DC., 2000. 1018 p.

BRAGAGNOLO, N.; RODRIGUEZ-AMAYA, D. B. Teores de colesterol, lipídios totais e ácidos graxos em cortes de carne suína. Ciência e Tecnologia de Alimentos, Campinas, v. 22, n. 1, p. 98-104, 2002.

Otimização da determinação de colesterol por CLAE e teores de colesterol, lipídios totais e ácidos graxos em camarão rosa (Penaeus brasiliensis). Ciência e Tecnologia de Alimentos, Campinas, v. 17, n. 3, p. 2227, 1997.

BRASIL. Ministério da Agricultura, Pecuária e Abastecimento. Instrução Normativa $n^{\circ} 21$, de 31 de Julho de 2000. Aprovar os regulamentos técnicos de identidade e qualidade de patê, de bacon ou barriga defumada e de lombo suíno. Diário Oficial [da] União, Seção 1, 12. p. 1-4, 2000.

Ministério da Saúde. Agência Nacional de Vigilância Sanitária. Resolução RDC n. 12, de 02 de janeiro de 2001. Regulamento Técnico sobre os padrões microbiológicos para alimentos. Diário Oficial [da] União, Seção 1, p. 1-47, 2001.

Portaria $\mathrm{n}^{\circ} 1.004$, de 11 de dezembro de 1998. Atribuição de função de aditivos, aditivos e seus limites máximos de uso para a categoria 8 - carne e produtos cárneos. Diário Oficial [da] União, Seção 1, p. $28,1998$.

COSTA, R. G.; MEDEIROS, A. N.; MADRUGA, M. $\mathrm{S}$. Rendimento de vísceras para buchada em caprinos Saanen alimentados com diferentes níveis de volumoso e concentrado. IN: SIMPÓSIO INTERNACIONAL SOBRE CAPRINOS E OVINOS DE CORTE, 2., 2003, João Pessoa. Anais... João Pessoa: EMEPA, 2003. p. 663666.

D'ARRIGO, M.; HOZ, L.; CAMBERO, I.; LOPEZBOTE, C. J.; PIN, C.; ORDÓÑEZ, J. A. Production of n-3 fatty acid enriched pork liver pâté. Food Science and Technology, London, v. 37, n. 6, p. 585-591, 2004.

DALMÁS, P. S.; BEZERRA, T. K. A.; MORGANOB, M. A.; MILANIB, R. F.; MADRUGA, M. S. Development of goat pâté prepared with 'variety meat'. Small Ruminant Research, Amsterdam, v. 98, p. 46-50, 2011.

DOOLAEGE, E. H. A.; VOSSEN, E.; RAES, K.; MEULENAER, B.; VERHÉ, R.; PAELINCK, H.; SMET, $\mathrm{S}$. Effect of rosemary extract dose on lipid oxidation, colour stability and antioxidant concentrations, in reduced nitrite liver pâtés. Meat Science, Barking, v. 90, n. 4, p. 925-931, 2012.

ECHARTE, M.; CONCHILLO, A.; ANSORENA, D.; ASTIASARÁN, I. Evaluation of the nutritional aspects and cholesterol oxidation products of pork liver and fish patés. Food Chemistry, Barking, v. 86, n. 1, p. 47-53, 2004.

ESTÉVEZ, M.; MORCUENDE, D.; RAMÍREZ, R.; VENTANAS, J.; CAVA, R. Extensively reared Iberian pigs versus intensively reared white pigs for the manufacture of liver pâté. Meat Science, Barking, v. 67, n. 3, p. 453-461, 2004.

ESTÉVEZ, M.; RAMÍREZ, R.; VENTANAS, S.; CAVA, $R$. Sage and rosemary essential oils versus BHT for the inhibition of lipid oxidative reactions in liver pâté. Food Science and Technology, London, v. 40, n. 1, p. 58-65, 2007.

ESTÉVEZ, M.; VENTANAS, S.; CAVA, R. Physicochemical properties and oxidative stability of liver pâté as affected by fat content. Food Chemistry, Barking, v. 92, n. 3, p. 449-457, 2005.

FERNÁNDEZ-LÓPEZ， J.; SAYAS-BARBERÁ, E.; SENDRA, E.; PÉREZ-ALVAREZ, J. A. Quality characteristics of ostrich liver Pâté. Journal of Food Science, Chicago, v. 69, n. 2, p. 85-91, 2004.

FOOD AND AGRICULTURE ORGANIZATION OF THE UNITED NATIONS - FAO. WHO. World Health Organization. Protein and amino acid requirements in human nutrition. Report of a Joint WHO/FAO/UNU Expert Consultation. 2007. Disponível em: <http:// whqlibdoc.who.int/trs/WHO_TRS_935_eng.pdf $>$. Acesso em: 13 jan. 2012.

FOOD AND DRUG ADMINISTRATION - FDA. Bacteriological analytical manual. Versão online 2011. Disponível em: <http://www.fda.gov>. Acesso em: 05 nov. 2011.

FERNÁNDEZ-LÓPEZ, J.; SAYAS-BARBERÁ, E.; SENDRA, E.; PÉREZ-ALVAREZ, J. A. Quality characteristics of ostrich liver Pâté. Journal of Food Science, Chicago, v. 69, n. 2, p. 85-91, 2004.

FOLCH, J.; LESS, M.; STANLEY, S. A. Simple method for the isolation and purification of total lipids from animal tissues. Journal of Biological Chemistry, United States, v. 226, p. 497-509, 1957. 
FONTES, P. R.; GOMIDE, L. A. M.; RAMOS, E. M.; STRINGHETA, P. C.; PARREIRAS, J. F. M. Color evaluation of carbon monoxide treated porcine blood. Meat Science, Barking, v. 68, n. 4, p. 507-513, 2004.

GORBATOV, V. M. Collection and utilization of blood proteins for edible purposes in the USRR. In: PEARSON, A. M.; DUTSON, T. R. (Ed.). Advances in meat research. New York: Elsevier Applied Science, New York, 1988. v. 5, p. 15-45.

GUERRA, I. C. D.; FÉLEX, S. S. S.; MEIRELES, B. R. L. M.; DALMÁS, P. S.; MOREIRA, R. T.; HONÓRIO, V. G.; MORGANO, M. A.; MILANI, R. F.; BENEVIDES, S. D.; QUEIROGA, R. C. R. E.; MADRUGA, M. S. Evaluation of goat mortadella prepared with different levels of fat and goat meat from discarded animals. Small Ruminant Research, Amsterdam, v. 98, n. 1-3, p. 59-63, 2011.

HARTMAN, L.; LAGO, R. C. A. Rapid preparation of fatty acids methyl esters. Laboratory Practice, United States, v. 22, n. 6, p. 475-476, 1973.

HONIKEL, K. O. The use and control of nitrate and nitrite for the processing of meat products. Meat Science, Barking, v. 78, n. 1-2, p. 68-76, 2008.

MADRUGA, M. A; SOUSA, W. H.; MENDES, E. M. S.; BRITO, E. A. Carnes caprina e ovina Processamento e fabricação de produtos derivados. Tecnologia e Ciência Agropecuária, João Pessoa, v. 1, n. 2, p. 61-67, 2007.

MADRUGA, M. S. Qualidade da carne caprina e ovina: recentes progressos e mercado. In: CONGRESSO BRASILEIRO DE CIÊNCIA E TECNOLOGIA DE CARNES, 5., 2009, São Paulo, 2009. Palestra... São Paulo: CBCTC, p. 1-16.

MATTOS, C. W.; CARVALHO, F. F. R.; DUTRA JÚNIOR, W. M.; VÉRAS, A. S. C.; BATISTA, A. M. V.; ALVES, K. S.; RIBEIRO, V. L; SILVA, M. J. M. S.; MEDEIROS, G. R.; VASCONCELOS, R. M. J.; ARAÚJO, A. O.; MIRANDA, S. B. Características de carcaça e dos componentes não-carcaça de cabritos Moxotó e Canindé submetidos a dois níveis de alimentação. Revista Brasileira de Zootecnia, Viçosa, v. 35, n. 5, p. 2125-2134, 2006.

MEILGAARD, M.; CIVILLE, G. V.; CARR, B. T. Sensory evaluation techniques. London: CRP Press, Inc., 1991. $287 \mathrm{p}$.

MINOZZO, M. G.; WASZCZYNSKYJ, N.; BOSCOLO, W. R. Obtenção de pate de armado (Pterodas granulosus) e a sua caracterização microbiológica, sensorial e físico-química. Brazilian Jornal of Food Technology, Campinas, v. 13, n. 3, p. 182-188, 2010.
MOREIRA-ARAÚJO, R. S. R.; ARAÚJO, M. A. M.; ARÊAS, J. A. G. Fortified food made by the extrusion of a mixture of chickpea, corn and bovine lung controls iron-deficiency anemia in preschool children. Food Chemistry, Barking, v. 107, n. 1, p. 158-164, 2008.

PELEGRINI, L. F. V.; PIRES, C. C.; KOZLOSKI, G. V.; TERRA, N. N.; BAGGIO, S. R.; CAMPAGNO, P. C. B.; GALVANI, D. B.; CHEQUIM, R. M. Perfil de ácidos graxos da carne de ovelhas de descarte de dois grupos genéticos submetidas a dois sistemas de manejo. Ciência Rural, Santa Maria, v. 37, n. 6, p. 1786-1790, 2007.

PINHO, O.; FERREIRA, I. M. P. L. V. O.; OLIVEIRA, M. B. P. P.; FERREIRA, M. A. Evaluation of nitrite and nitrate contents of liver pâtés. Food Chemistry, Barking, v. 62 , n. 3, p. 359-362, 1998.

PIRES, C. V.; OLIVEIRA, M. G. A.; ROSA, J. C.; COSTA, N. M. B. Qualidade nutricional e escore químico de aminoácidos de diferentes fontes protéicas. Ciência e Tecnologia de Alimentos, Campinas, v. 26, n. 3, p. 179187, 2006.

POLAK, T.; ZLENDER, B.; LUSNIC, M.; GASPERLIN, L. Effects of coenzyme Q10, $\alpha$-tocopherol and ascorbic acid on oxidation of cholesterol in chicken liver pâté. Food Science and Technology, London, v. 44, n. 4, p. 1052-1058, 2011.

SANTOS, E. M.; DIEZ, A. M.; GONZÁLEZFERNÁNDEZ, C.; JAIME, I.; ROVIRA, J. Microbiological and sensory changes in "Morcilla de Burgos" preserved in air, vacuum and modified atmosphere packaging. Meat Science, Barking, v. 71, n. 2, p. 249-255, 2005.

SANTOS, E. M.; FERNANDÉZ, C. G.; JAIME, I.; ROVIRA, J. Physicochemical and sensory characterisation of Morcilla de Burgos, a traditional Spanish blood sausage. Meat Science, Barking, v. 65, n. 2, p. 893-898, 2003.

SEBRANEK, J. G.; BACUS, J. N. Cured meat products without direct addition of nitrate or nitrite: what are the issues? Meat Science, Barking, v. 77, n. 1, p. 136-147, 2007.

SILVA, V. D. M.; SILVESTRE, M. P. C. Functional properties of bovine blood plasma intended for use as a functional ingredient in human food. Food Science and Technology, London, v. 36, n. 7, p. 709-718, 2003.

STIEBING, A. Blood sausage technology. Fleischwirtschaft, Germany, v. 70, n. 4, p. 424-428, 1990.

THAUTWEIN, E. A. N-3 fatty acids e physiological and technical aspects for their use in food. European Journal of Lipid Science Technology, Germany, v. 103, n. 1, p. 45-55, 2001. 
USDA. Nutrient values and weights are for edible portion. NDB N 0310, Babyfood, meat, lamb, strained. Nutrient database for standard reference. 2012. Disponível em: $<$ http://ndb.nal.usda.gov>. Acesso em: 06 mar. 2012a.

. NDB $\mathrm{N}^{\circ} 07055$, Pate, liver, not specified, canned. Nutrient database for standard reference. 2012. Disponível em: <http://ndb.nal.usda.gov>. Acesso em: 06 mar. 2012b.

. NDB $\mathrm{N}^{\circ}$ 17224, lamb, ground, raw. Nutrient database for standard reference. 2012. Disponível em: <http://ndb.nal.usda.gov>. Acesso em: 06 mar. 2012c.
VOSSEN, E.; EVELYNE, H. A.; DOOLAEGE, H.; DEMEWEZ, M.; BRUNO, M.; SLAWOMIR, S.; KATLEEN, R.; STEFAAN, S. Effect of sodium ascorbate dose on the shelf life stability of reduced nitrite liver pâtés. Meat Science, Barking, v. 91, n. 1, p. 29-35, 2012.

WHITE, J. A.; HART, R. J.; FRY, J. C. An evaluation of the waters pico-tag system for the amino-acid analysis of food materials. Journal of Automatic Chemistry, United States, v. 8, n. 4, p. 170-177, 1986.

WILLIAMS, P. G. Nutritional composition of red meat. Nutrition \& Dietetics, Australia, v. 64, n. 4, p. 113-119, 2007. 